by Peter D. Kruse*

\title{
Proposal for a scale of Cambrian subsystems (if such is needed at all)
}

South Australian Museum, PO Box 825, Normanville SA 5204, Australia; *Corresponding author, E-mail: archaeo.kruse@gmail.com

(Received: December 3, 2020; Revised accepted: February 16, 2021)

https://doi.org/10.18814/epiiugs/2021/021004

A recently proposed subsystem scale seeks to overlay a threefold subsystem scheme onto the four-series Cambrian. It does this by uniting the two lowest global series within a single subsystem, whereas the remaining two subsystems coincide with the global Miaolingian and Furongian series. This is an impractical scheme, strongly influenced by historical precedent, and an alternative scheme of two subsystems, each comprising two global series, is here proposed.

\section{Introduction}

Landing et al. (2020) have recently proposed a threefold scale of subsystems for the Cambrian, which now comprises four global series and ten stages following a 2004 decision by the International Subcommission on Cambrian Stratigraphy (ISCS) (e.g., Babcock et al., 2005). Significantly, the 2004 decision superseded the previous tradition of a Cambrian consisting of three series/epochs (generally termed Lower/ Early, Middle and Upper/Late), and was largely prompted by the recognition that the subtrilobitic Lower Cambrian was sufficiently thick and fossiliferous to warrant definition as a separate series. In addition, the boundaries of each series/epoch had previously been placed at a chronostratigraphic level that varied from region to region (e.g., Robison et al., 1977; Geyer and Shergold, 2000; Peng et al., 2020). Formal use of the traditional series/epoch names was therefore discouraged, and the use of informal lower-case equivalents (lower/early, middle, upper/ late) has continued to the present. It is noteworthy that a four-series precedent had been set by Landing et al. (1989) and Landing (1992), who recognised series respectively approximating to the traditional subtrilobitic Lower Cambrian, trilobitic Lower Cambrian, Middle Cambrian and Upper Cambrian on the Avalonia palaeocontinent (see, also Peng and Babcock, 2012). Landing et al. (2020) provide an ample account of the historical development of the Cambrian chronostratigraphic scale.

\section{Subsystems}

The proposal of Landing et al. (2020) is for the adoption of a scale of three Cambrian subsystems, the lowest of which embraces the two lowest global series, whereas the remaining two coincide with the global Miaolingian and Furongian series. These are proposed to be named Lower Cambrian Subsystem, Middle Cambrian Subsystem and Upper Cambrian Subsystem (with their corresponding Subperiods). These names, used in full, are intended to eliminate any confusion with the former, traditional series/epochs (though in practice they will be abbreviated to Lower Cambrian, etc, by many authors, thereby retaining the potential for confusion). In proposing their scheme, Landing et al. (2020) strongly emphasise the role of historical precedent.

This proposal follows from the introduction by Landing (1998, p. 2) of a Lower Cambrian Subsystem comprising his Avalonian Placentian and Branchian series. While Landing et al. (2020) outline examples of putative unwitting introductions of subsystem-level units in the literature, that of Landing (1998) appears to be the first explicit proposal of a Cambrian subsystem.

\section{Alternative Subsystem Proposal}

Is a subsystem hierarchical level needed at all for the Cambrian? Like the Cambrian as currently subdivided (see, $<$ https://stratigraphy.org/ ICSchart/ChronostratChart2020-03.pdf $>$ ), the Silurian System includes four series, which carry geographic names. The Permian and Palaeogene each include three series yet respectively carry geographic and historical names. Only the Carboniferous includes (two) recognised subsystems (e.g., Cohen et al., 2013; Gradstein et al., 2020).

Landing et al. (2020) interpret the continued use of lower/early, middle and upper/late divisions of the Cambrian, either informally (lowercase) or apparently formally (with initial capitals), to indicate that these tripartite units are convenient, useful and natural. They rightly deplore the continued use of the informal terms, as they are either undefined, illdefined or only regionally applicable, and their 'solution' to the problem is to formalise them as above. On the contrary, in my view this ongoing usage is simply a hangover from the former traditional scheme, and will lose its value and appeal once the global scheme is fully defined.

Unlike Landing et al. (2020), I do not necessarily advocate the introduction of another (subsystem) level to the Cambrian chronostratigraphic hierarchy. However, it is possible that the ISCS may consider this possibility in the future. For this reason, I offer an alternative subsystem scale for future consideration.

To have any practical use, each unit in any hierarchical level should include two or more units of the immediately subordinate level. Units 
that do not do so merely duplicate the subordinate level and only serve to add additional jargon. (It must be acknowledged that the Silurian and Carboniferous incorporate series that include only a single stage, but I submit that these instances are anomalies, indicative of a desire or determination to retain historically entrenched names.) In the case of the Cambrian, this means that the Middle Cambrian Subsystem and Upper Cambrian Subsystem of Landing et al. (2020), which precisely duplicate the defined global Miaolingian and Furongian series respectively, serve no real practical purpose. Their subsystem scheme is intended to perpetuate the traditional tripartite subdivision of the Cambrian (albeit redefined in respect to their lowest subsystem), by overlaying a threefold subsystem scale onto the fourfold global series scale.

I contend that application of the above-stated principle to the fourfold Cambrian can lead to only one unique solution: any Cambrian subsystem division, to be of practical use, must consist of two groupings, each of two series. Unlike the approach of Landing et al. (2020), this present proposal owes nothing to historical precedent or entrenched usage; it relies solely on logic to create a practical, forward-looking subsystem scale for the Cambrian (if such is judged to be needed at all). As stated by Geyer and Shergold (2000, p. 189), 'In the search for divisions of the Cambrian, the traditional series boundaries should not be regarded as holy shrines.' The scale proposed here is analogous to that of the Cretaceous in that it comprises two series (there termed Lower and Upper).

I feel obliged to conclude by addressing the issue of naming of the two proposed Cambrian subsystems. Adoption of the standard adjectives would produce Lower and Upper Cambrian subsystems (as in the Cretaceous). With respect to the Cambrian, I acknowledge that absorption of the traditional Middle Cambrian into an expanded Upper Cambrian may, at least initially, engender some confusion with former usage. If this is judged to be likely, geographic names may be applied (Salvador, 1994).

\section{Conclusion}

I hereby formally propose for consideration by the ISCS that, should a subsystem scale for the four-series Cambrian be judged to enhance scientific communication, a twofold subdivision, wherein each subsystem encompasses two global series, is the most logical and practical scenario.

\section{References}

Babcock, L.E., Peng, S., Geyer, G., and Shergold, J.H., 2005, Changing perspectives on Cambrian chronostratigraphy and progress toward subdivision of the Cambrian System. Geosciences Journal, v. 9, pp. 101-106.

Cohen, K.M., Finney, S.C., Gibbard, P.L., and Fan, J., 2013. The ICS International Chronostratigraphic Chart. Episodes, v. 36, pp. 199-204.

Geyer, G., and Shergold, J.H., 2000, The quest for internationally recognized divisions of Cambrian time. Episodes, v. 23, pp. 188-195.

Gradstein, F.M., Ogg, J.G., Schmitz, M.D., and Ogg, G.M. (Eds.), 2020, Geologic Time Scale 2020. Elsevier, Amsterdam, 1357 pp.

Landing, E., 1992, Lower Cambrian of southeastern Newfoundland. Epeirogeny and Lazarus faunas, lithofacies-biofacies linkages, and the myth of a global chronostratigraphy. In: Lipps, J.H., and Signor, P.W. (Eds.), Origin and early evolution of the Metazoa. Plenum, New York, pp. 283-309.

Landing, E., 1998, Avalon 1997-a pre-meeting viewpoint. In: Landing, E., and Westrop, S.R. (Eds.), Avalon 1997-the Cambrian standard. New York State Museum Bulletin, 492, pp. 1-3.

Landing, E., Geyer, G., Schmitz, M.D., Wotte, T., and Kouchinsky, A., 2020, (Re)proposal of three Cambrian subsystems and their geochronology. Episodes, doi:10.18814/epiiugs/2020/020088

Landing, E., Myrow, P., Benus, A.P., and Narbonne, G.M., 1989, The Placentian Series: appearance of the oldest skeletalized faunas in southeastern Newfoundland. Journal of Paleontology, v. 63, pp. 739-769.

Peng, S.C., and Babcock, L.E., 2012, Rejoinder: Four-series concept of the Cambrian has a long history. Bulletin of Geosciences, v. 87, pp. 629632.

Peng, S.C., Babcock, L.E., and Ahlberg, P., 2020, Chapter 19: The Cambrian Period. In: Gradstein, F.M., Ogg, J.G., Schmitz, M.D., and Ogg, G.M. (Eds.), Geologic Time Scale 2020. Elsevier, Amsterdam, pp. 565-629.

Robison, R.A., Rosova, A.V., Rowell, A.J., and Fletcher, T.P., 1977, Cambrian boundaries and divisions. Lethaia, v. 10, pp. 257-262.

Salvador, A. (Ed.), 1994, International stratigraphic guide. A guide to stratigraphic classification, terminology, and procedure (2nd edition). International Union of Geological Sciences and Geological Society of America, Inc., Boulder, xix+214 pp.

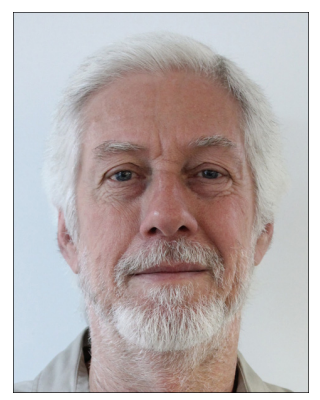

Peter D. Kruse is a palaeontologist and stratigrapher with interests primarily in the Cambrian. He received his B.Sc.(Hons) and Ph.D. degrees from the University of Sydney, Australia. He spent the bulk of his working life with the Northern Territory Geological Survey, Darwin, mapping and researching the Northern Territory's sedimentary basins. For many years he was Convener of the Northern Territory Stratigraphic Names Subcommittee, Geological Society of Australia. His palaeontological interests focus on archaeocyaths but also encompass other Cambrian fossil groups, as well as the sedimentology of Cambrian reefs. He is a Voting Member of ISCS. 